\title{
Contribution to the flora of Um Rimmitta area, White Nile State, Sudan ${ }^{1}$ A.K. Elsafori, ${ }^{2}$ A.N.Gumma and ${ }^{3}$ M.A. E Nour \\ ${ }^{1}$ College of Forestry and Range Science, Sudan University of Science and Technology, Khartoum, Sudan \\ ${ }^{2}$ Faculty of Education, U.o.K. Sudan. \\ ${ }^{3}$ Faculty of Forestry, U.o.K. Sudan. \\ ${ }^{1}$ Current Address: Faculty of Meteorology, Environment, and Arid Land Agriculture King Abdul Aziz University, Jeddah, K.S.A
}

\begin{abstract}
The study deals with the ecology and taxonomy of the vegetation of Um Rimmitta area, Central Sudan. Taxonomic studies included collection, preparation, identification and classification of plant species in the study area. A total of 85 plant species were identified belonging 030 families, represent the flora of the study area. From the identified species of the present study, (42) species were found to have medicinal values, and these represented (49.4\%), of the total plant species of the study area. Moreover, a check-list of endangered, extinct and famine food plants has been provided. The study shown that during the drought spells in 1975, 1980, some of the plant species at the study area were lost. Also the study found that some plant species supported that locals during the period $s$ of drought and bridged the gap in food supplies. The present study revealed that the soil moisture content was relatively low at the study area. The chemical analysis of the soil shown that there were no significant differences between sites in the study area with respect to soil elements. However, there were significant different between the sites in their $\mathrm{pH}$ values.
\end{abstract}

Key words: Identification, classification, plant species, medicinal values, endangered, Threatened, extinct species, famine plants, drought spells, rainfall flucutations and Arid climates.

\section{INTRODUCTION}

Sudan exhibits a wide range of variation in its topography, climate, soil and hydrology. This resulted in different ecological habitats, different vegetation zones and consequently rich flora.

Studies on the flora of vegetation were few represented by the work of Braun and Massey (1929) and Andrews (1950, 52, 56), which may be regarded as the standard refrnce floras of the area. Racenty, El Amin (1990) made valuable attempts to update the trees and shrubs of the Sudan.

Studies on regional floras include the work of Crowfoot (1928), Andrews (1949), Obied and Mahmoud (1968), Ahtiet et al. (1973), Hassan (1974), Wickens (1976), Thirakul (1984) and Bebawi and Neugebhorn (1991), El Awad (1981, 1995), El Gazali
(1985, 1986), Kordofani (1985), Gumaa (1988), Ibrahim (1996), Abdalla (1997), El Safori (2000).

The study area belongs to semi-desert scrub and grass land, with an average annual rainfall 75$250 \mathrm{~mm}$. the flora of um Rimmtta was selected for investigation in the present study for a number of reasons; Firstly, few number of specimens previously collected from the study area weren't encountered in various herbaria that need to be updated and incorporated in the main flora of Sudan. Secondly, the last few years witnessed the prevalence of good rain seasons which would support the actual flora of the area. The main factor which determines the distribution of the vegetation is the rainfall. The main objective of this study is document the flora of the study area and consequently to contribute in updating the Sudan flora. 
The study area: The study area lies between latitudes $14^{\circ} 36$ and $14^{\circ} 49 \mathrm{~N}$ and longitude $32^{\circ} 05^{\prime}$ and $32^{\circ} 11^{\prime} \mathrm{E}$.

The climate is atypical tropical continental characterized by warm dry winters and hot rainy season. The study area is generally characterized by high temperatures from most of the year, with means of $37^{\circ} \mathrm{C}$ and $21^{\circ}$ for maximum and minimum summer temperature respectively.

The rainy season extends from June to October and most of the rains fall during July and August. The average annual rainfall had declined from $330 \mathrm{~mm}$ (1920-1950) to $248 \mathrm{~mm}$ (1960-1995). The great variations in rainfall are characteristic of arid climates, Halwagy (1961).

Generally, the mean relative-humidity percentage is the lowest in April (10\%) and the highest in August (67\%). The mean daily evaporation is the highest in April $(2.00 \mathrm{~mm})$ and the lowest in August $(10.8 \mathrm{~mm})$. Clouds prevail almost six months in the year, whereas the mean sunshine is 3650 hours/year. The north-east or northerly trade winds prevail during the winter, whereas the south-east winds prevail during the autumn. The dust storms (haboobs) are common in the summer seasons.

\section{MATERIALS AND METHODS}

The study area falls within the semi-desert region. Direct observations and primary surveying were used to assess environmental conditions and plant community type. The global positioning system (GPS) was used to determine the images of the study area.

Collection of materials and preparation of specimens: Plant specimens were collected from different sites of the study area at different times of the year 2003 and 2004. The whole plant was collected for in case of herbs and twigs with leaves and flowers and /or fruits in case of shrubs and trees. The specimens were stretched to dry between newspapers and firmly pressed inside a herbarium press. Newspaper were continuously changed during the drying to avoid rotting of material finally; the specimens were mounted, labeled and deposited at the herbarium of the Medicinal and Aromatic Plants
Research Institute (MAPRI), National Centre for Research (NCR), Khartoum. Field observations were recorded which included, habit, habitat, distribution and colors of flowers and liquid during the collection trips. In the herbarium further analysis and /or identification were done, initially by examining the various parts of the specimens collected by using a hand-lens. Fine floral characters were examined under Mbc-10 dissection microscope. A preliminary species identification was carried out using a set of keys (Andrews, 1950, 52, 56), Hutchinson and Dalziel (1963), and Braun et al (1991). The identified species were compared with already identified herbarium specimens from herbaria of Forestry Research Centre, Faculty of Science University of Khartoum and Medicinal and Aromatic Plants Research Institute, National Centre of Research, Khartoum-Sudan.

The synonyms of the identified species were extracted from many references such as (Hutchinson and Dalziel, 1963), index Kewensis (1885-1965), Wickens (1976), Sahni (1968), El Awad (1995), ElGhazali et al. (1987) and El Amin (1990).

The vernacular names of species were recorded from local inhabitants within the study area and also extracted from Braun and Massey (1929), (Andrews (1949, 53, 56), Wickens (1976). For citation of species only the oldest reference was cited (Sp. PI. in most cases), in addition Andrews (1950, 52, 56) was also cited.

Medicinal folkloric uses of collected species have been provided. These uses have been extracted from available literature on Sudanese plants or plants of neighboring countries (ElGhazali et al 1994), in addition some information were obtained from the inhabitants of the study area.

Soil Moisture: The gravimetric method was used to measure the soil moisture. The soil samples were weighed and oven-dried, for 24 hours at $105^{\circ} \mathrm{c}$. The samples were then reweighed and their moisture content is expressed as a percentage of the dry weight as follows:

M.C. $\%=\frac{W^{1} W^{2}}{W^{1}} \times 100$ 
Soil Chemical Analysis: The soil samples were chemically analyzed for $\mathrm{pH}$, Organic matter (O.M.), Nitrogen $(\mathrm{N})$, Phosphorus $(\mathrm{P})$ and Potassium (K).

\section{The pH was determined by using Calorimetric} methods: The organic matter was determined by using the combustion method while the nitrogen was determined by using Kjeldahl method. The phosphorus was determined by digestion and calorimetric method. The potassium was determined by the flame photometer method.

\section{RESULTS}

The collection from the study area has been covered different habitats and a total number of (85) plant species belong to 30 families were identified (28 Dicotyledons and 2 Monocotyledons) Tale (1). Some families were represented by a number of species while others are represented by only one species from the identification species of the present study, (42) species were found to have medicinal values and these represented $(49.4 \%)$ of the total flora.

Table 1. Flora of Um Rimmitta area, Central Sudan, in 2006

\begin{tabular}{|c|c|c|c|}
\hline Family & Species & Vern. Name & Habit \\
\hline Aizoaceae & Mullugo nudicaulisLam. & ShamarKazib & An., He. \\
\hline Aizoaceae & Zaleya pentandra(L.) & Al-Rabaa & An., He. \\
\hline Amaranthaceae & Aerva javanica(Burm.f.) & Raselshaib & Per.,He \\
\hline Amaranthaceae & Alternanthera nodifloraForssk. & Abuturma & An., He. \\
\hline Amaranthaceae & Amaranthus graecizans $\mathbf{L}$. & Lissantairsaghir & An.,He. \\
\hline Amaranthaceae & Celosia argentea $\mathrm{L}$. & DanabEkalib & An., He. \\
\hline Amaranthaceae & Diger amuritica(L.) & LablabAhmr & An., He. \\
\hline Aristolochiaceae & Aristolochia bracteolate Lam & Um Galagil & Per.,He. \\
\hline Asclepiadaceae & Leptadeni apyrotechnica(Forssk.) & Marekh & Shrub \\
\hline Asclepiadaceae & Leptadenia arborea & " & Twin. \\
\hline Asteraceae & Sonchu scornutusHochst.ex & $"$ & Per.,He. \\
\hline Asteraceae & Sonchus oleraceousL. & Moleita & An., He. \\
\hline Asteraceae & Xanthium brasilicum Waller. & Ramtouk & An., He. \\
\hline Balanitaceae & Balanites aegyptiaca(L.) & Hegleeg & Tree \\
\hline Boraginaceae & Heliotropium supinumL. & DanabElagrab & An., He. \\
\hline Brassicaceae & Farsetia hamiltoniiRoyle. & " & An., He. \\
\hline Brassicaceae & Farsetia longsiliquaDence. & Um Adafir & An., He. \\
\hline Brassicaceae & Matthiola & & \\
\hline Burseraceae & Commiphora africana (A.Rich.) & Gafal & Tree \\
\hline Caesalpiniaceae & Senna alexandrinaMill. & Senna Makah & Per.,He. \\
\hline Capperidaceae & Boscia senegalensis(Pers.) & Kursan & Tree \\
\hline Capperidaceae & Capparis deciduas(Forssk.) & Tundub & Tree \\
\hline Capperidaceae & Maerua crassifolia(Forssk.) & Sareh & Tree \\
\hline Cleomaceae & Cleome gynandraL. & Tamalaika & An., He. \\
\hline Convolvulaceae & Ipomoea cordofanChoisy. & Tabr & An., He. \\
\hline Convolvulaceae & Ipomoea aquaticForssk. & Abu Halageem & Trai.,He \\
\hline Cucurbitaceae & Cucumi smelo.var.argestisNaud. & Seinat & Clim. He \\
\hline Cucurbitaceae & Luffa echinata Roxb. & Leef & Clim. He \\
\hline Euphorbiaceae & Acalypha indicaL. & El Matraba & An., He. \\
\hline Euphorbiaceae & Euphorbia aegyptiacaBioss. & Um Lebaina & An., He. \\
\hline Fabaceae & Alysicarpus vaginalis(L.) & Shillini & An., He. \\
\hline Fabaceae & Crotalaria pyconstachyaBenth. & - & An.,He. \\
\hline Fabaceae & Desmodium dichotomum(Klein) & Abu Araida & Und. Sh \\
\hline Fabaceae & Indigofera hochstetteriBak. & Sharaia & Diff.,He \\
\hline
\end{tabular}




\begin{tabular}{|c|c|c|c|}
\hline Fabaceae & Indigofera oblongifoliaForssk. & Dahassir & Und.Sh. \\
\hline Fabaceae & Indigofera strobiliferaHochst. & " & Und.Sh. \\
\hline Fabaceae & Rynchosia minimavar.minima(L.) & AdanElfar & Twin. \\
\hline Fabaceae & Sesbania sesban (L.) & Sesban & Shrub \\
\hline Fabaceae & Tephrosia unifloraPers. & Amoyoga & Per.,He. \\
\hline Lamiaceae & Ocimum canumSmis. & Raihan & An., He. \\
\hline Lamiaceae & Ocimum basilicumL. & Raihan & An., He. \\
\hline Loranthaceae & Loranthus acaciaeZucc. & Anaba & Clim. \\
\hline Malvaceae & Abutilon figarianumWebb. & Ambru & Per.,He. \\
\hline Malvaceae & Hibiscus vitifoliusL. & $"$ & An., He. \\
\hline Mimosaceae & Acacia mellifera(Vahl.) & Kitir & Tree \\
\hline Mimosaceae & Acacia niloticasubsp.nilotica(L.) & Sunt & Tree \\
\hline Mimosaceae & Acacia oerfota(Forssk.) & Laot & Shrub \\
\hline Mimosaceae & Acacia seyalvar.seya/Del. & Talih & Tree \\
\hline Mimosaceae & Acacia tortilissubsp.spirocarpaForssk & Samur & Tree \\
\hline Mimosaceae & Acacia tortilis subsp.raddianaForssk. & Seyal & Tree \\
\hline Mimosaceae & Faidherbia albida(Del.) & Haraz & Tree \\
\hline Nyctaginaceae & Boerhavia repens var. diffusa $\mathbf{L}$. & Rubaa & An., He. \\
\hline Pedaliaceae & Sesamum alatumThonn. & SimsimGumal & An., He. \\
\hline Portulaceae & Portulaca oleraceaL. & Rigla & An., He. \\
\hline Portulacaceae & Portulaca quadrifidaL. & Um Mamleeha & An., He. \\
\hline Rhaminacaea & Ziziphus spina-christi (L.) & Sidder & Tree \\
\hline Rubiaceae & Kohautica aspera (L.) & Um Hebiag & An., He. \\
\hline Salvadoraceae & Dobera glabra(Forssk.) & Maikah & Tree \\
\hline Salvadoraceae & Salvadora persicaL. & Arak & Tree \\
\hline Solanaceae & Physalis angulata $\mathbf{L}$. & Karmkarm & An.,He. \\
\hline Solanaceae & Solanum coagulansForssk. & Gubbain & Per.,He. \\
\hline Solanaceae & Solanum nigrumL. & EinabEldeeb & An.,He. \\
\hline Tiliaceae & Corchoru sdepressus Stocks. & Umshiteh & Per.,He. \\
\hline Tiliaceae & Corchorus fascularisLam. & khudra & Per.,He. \\
\hline Tiliaceae & Corchoru strilocularisL. & KhudraKhala & An.,He. \\
\hline Zygophyllaceae & Fagonia creticaL. & Umshoweika & An.,He. \\
\hline \multirow[t]{2}{*}{ Zygophyllaceae } & Tribulu sterrestrisL. & Dereisa & An.,He. \\
\hline & Monocotyledons & & \\
\hline Cyperaceae & Cyperus rotundus $\mathbf{L}$. & Seida & Per.,He. \\
\hline Cyperaceae & Fimbristylis-umbellata (Forssk.) & DignEltais & An., He. \\
\hline Poaceae & Aristida adscensionisL. & Humra & An., He. \\
\hline Poaceae & Brachiari amuticaStapf. & Korraib & Per.,He. \\
\hline Poaceae & Brachiari areptans(L.) & Umkewaiat & An.,He. \\
\hline Poaceae & Cenchrus biflorusRoxb. & Haskaneet & An.,He. \\
\hline Poaceae & Chloris virgataSwartz. & UmFaru & An.,He. \\
\hline Poaceae & Cynodon dactylon(L.) & Nagil & Per.,He. \\
\hline Poaceae & Dactyloctenium aegyptium(L.) & UmAsabiaa & An., He. \\
\hline Poaceae & Dicanthum annulatumStpf. & Lukh & Per.,He. \\
\hline Poaceae & Dinebera retroflexa (Vahl.) & Um Maliha & An., He. \\
\hline
\end{tabular}


Agric. Biol. J. N. Am., 2012, 3(10): 427-434

\begin{tabular}{|l|l|l|l|}
\hline Poaceae & Eragrostis cilianensis(Au.) & BannuMaleh & An.,He. \\
\hline Poaceae & Eragrostis tenella(L.) & Bannu & An.,He. \\
\hline Poaceae & Panicum turgidumForssk. & Tumam & Per.,He. \\
\hline Poaceae & Pennisetum pedicelltumTrin. & An.,He. \\
\hline Poaceae & Schoenfeldia gracilisKunth. & ZanabElnaga & An.,He. \\
\hline Poaceae & Setaria verticillata(L.) & Lussaig & An.,He. \\
\hline Poaceae & Sorghum purpureosericum(Hochst.) & Adar & An.,He. \\
& & & \\
\hline
\end{tabular}

Key: An. $=$ Annual, He. $=$ Herb, Per. $=$ Perennial, clim. $=$ Climber, Dif. $=$ diffused

Trai.= Trailer, Und.sh= Under shrub., Twin: Tiwinner

\section{DISCUSSION}

The results of the present study, as compared to Andrews (1948), have shown that the species Cadaba farinosa and Cymbopogon nervatus had completely disappeared from the study area. This may be attributed to fluctuations in rainfall and excessive land use or selected pressure on these species.

Comparing the results of the present study with those of Harrison and Jackson (1929), it can be seen that Cymbopagon promimus and Blepharis linarrifolia had completely disappeared from the study area. This probably due to fluctuations of rainfall, sand drifts, over-grazing and excessive land use. The present study reported similar findings to those of Wicknes (1976), except that Salvadora persica has become a rare species. This may be due to the demand and heavy use of this tree as a source of income through marketing its branches as a substitute for tooth brushes. The present study reported the same findings of Nordwijk (1984) for the species Acacia tortilis and Maerua crassifolia but has noted that Acacia mellifera and Commiphora africana were very small in numbers. This may be due to the felling for charcoal production and building construction by locals.

The present study revealed that some woody species are threatened, as seen from their low abundance in the study area. These species included Salvadora persica, Commiphora africana, Acacia mellifera, Acacia seyal and Dobera glabra. The threat is probably due to soil deterioration, excessive use, drought periods, rainfall fluctuations, over grazing and the increasing human and animal populations.
Similarly some herbs and grasses had completely disappeared from the study area e.g. Cymbopogon proximus,Blepharis linarrifolia andStipagrostis plumosa. This may be attributed to over-grazing and utilization, sand drifts and rainfall fluctuations.

The threatened and endangered species have been presented in Table (2). Some species have completely disappeared from the study area, while others are now threatened table (3). The main causes of these vegetation changes can be summarized as follows: Drought spells, multiple-uses of these species, excessive felling of woody species of satisfy human needs, over-grazing, increased shifting cultivation, climatic changes, excessive drilling of wells in the region, increased human and animal population, voluntary or compulsory settlement of the nomads whose mode of life adversely affects vegetation cover and the petroleum industries. During the drought spells of 1980, there was as severe shortage of food and hence the locals had to find alternative plant sources for food, such alternative plant species are currently referred to as famine foods these species supported the locals during the period of drought and bridged the gap in food supplies. A list of famine food species presented in table (4).

The results of the soil moisture analysis are presented in table (5). The moisture content in the study are was very low. This is probably due to the decrease in vegetation cover, increase in run-off \& erosion, low quantity of organic matter and rainfall fluctuations. The results of the soil characteristics were out lined in table (6) .

The soils of the study area were classified as alkaline and acidic soils. The organic matter and nutrients 
were less available. The low availability may be affected by scarcity of vegetation cover, run-off and erosion.

The plants conservation must be considered so as to reduce the encroachment of desertification and to preserve plant species of economic importance and medicinal value. There is vital need for reseeding or replanting extinct plant species. Management of these plants should conform to the ecological factors prevailing in the study area. Also there is vital need for more research on nutritional values of famine food plants which will provide a potential substitute for traditional food crops.

The study area is generally sparsely vegetated and has very low species diversity. Attention should be paid to land use planning and resource utilization and conservation in accordance with the national and commission regulation.

Table(2): Endangered and threatened species at the study area:

\begin{tabular}{|r|r|r|r|}
\hline Family & Species & Vern. names & Habit \\
\hline Burseraceae & Commiphora africana & Gafal & Tree \\
\hline Mimosaceae & Acacia mellifera & Tree \\
\hline Mimosaceae & Acacia seyalvar.seyal & Talih & Tree \\
\hline Salvadoraceae & Dobera glabra & Maikah & Tree \\
\hline Salvadoraceae & Salvador apersica & Arak & Tree \\
\hline
\end{tabular}

Table (3): Extinct plant species at the study area:

\begin{tabular}{|l|l|l|l|}
\hline Family & Species & Vern. names & \multicolumn{1}{|c|}{ Habit } \\
\hline Acanthaceae & Blepharis linarriifolia & Begail/Seha & Herb \\
\hline Boraginaceae & Cordia rothii & Andrab & Tree \\
\hline Boraginaceae & Trichodesma africanum & El Heirsh & Herb \\
\hline Combretaceae & Combretum aculeatum & Sheheit & Shrub \\
\hline Elatinaceae & Bergia suffruticosa & El Rimmit & undershrub \\
\hline Fabaceae & Dalbergia melanoxylon & Abanous & Tree \\
\hline Fabaceae & Indigofera suavolens & Singid & Climber \\
\hline Liliaceae & Aspragus racemosus & Diayok & Climber \\
\hline Malvaceae & Cienfuegosi digitata & El Gutub & Shrub \\
\hline Pedaliaceae & Ceratotheca sesamoides & Abadieb & Herb \\
\hline Poaceae & Chrysopogon aucheri & Aigrab & Herb \\
\hline Poaceae & Cymbopogon proximes & Mahareib & Herb \\
\hline Poaceae & Tragus berteronianus & El Rabul & Herb \\
\hline Tiliaceae & Grewia mollis & Basham & Tree \\
\hline Tiliaceae & Grewia tenax & Gudiem & Shrub \\
\hline Tiliaceae & Grewia villosa & Geraigdan & Shrub \\
\hline
\end{tabular}


Table (4): Famine food plant species at the study area:

\begin{tabular}{|l|l|l|l|l|}
\hline \multicolumn{1}{|c|}{ Family } & Species & Vern. names & Habit & Parts used \\
\hline Balanitaceae & Balanites aegyptiaca & Hegleig & Tree & Fruits \\
\hline Capparidaceae & Boscia senegalensis & Mokhiet & Tree & Fruits \\
\hline Capparidaceae & Capparis decidua & Tundub & Tree & Fruits \\
\hline Capparidaceae & Maeru acrassifolia & Sareh & Tree & Fruits \\
\hline Poaceae & Brachairi amutica & Korieb & Herb & Seeds \\
\hline Poaceae & Cenchrus biflorus & Haskaneit & Herb & Seeds \\
\hline Poaceae & Dactyloctenium aegyptium & Um Asabie & Herb & Seeds \\
\hline Poaceae & Panicum turgidum & Tumam & Herb & Seeds \\
\hline Rhamnaceae & Ziziphus spina-christi & Sidr & Tree & Fruits \\
\hline Salvadoraceae & Dober aglabra & Maikah & Tree & Fruits \\
\hline Tiliaceae & Grewia tenax & Gudiem & Shrub & Fruits \\
\hline Tiliaceae & Grewia villosa & Geraigdan & Shrub & Fruits \\
\hline
\end{tabular}

Table (5): Moisture content at the study area:

\begin{tabular}{|l|c|c|l|}
\hline Sites & \multicolumn{2}{|c|}{ Depths(cm) } & Mean \\
\hline A & $0 \quad 30 \quad 30 \quad 60$ & 18.8 \\
\hline B & $23.3 \%$ & $2.2 \%$ & 3.9 \\
\hline C & $5.6 \%$ & $5.4 \%$ & 7.2 \\
\hline Mean & $8.9 \%$ & 7.3 & 9.92 \\
\hline
\end{tabular}

Table (6):Soil chemical analysis:

\begin{tabular}{|c|c|c|c|c|c|c|}
\hline Sites & Depths & PH & $\mathrm{K}\left(\mathrm{Mmol}^{+}\right)$ & O.M.\% & $\mathrm{N} \%$ & $P$ (mg) \\
\hline A & $\begin{array}{ll}0 & 30 \\
30 \_ & 60\end{array}$ & $\begin{array}{l}7.01 \\
7.45 \\
\end{array}$ & $\begin{array}{l}0.17 \\
0.34\end{array}$ & $\begin{array}{c}0.014 \\
0.012\end{array}$ & $\begin{array}{l}0.08 \\
0.11\end{array}$ & $\begin{array}{l}1.54 \\
3.37 \\
\end{array}$ \\
\hline B & $\begin{array}{ll}0 & 30 \\
30 & 60\end{array}$ & $\begin{array}{l}6.10 \\
5.60\end{array}$ & $\begin{array}{l}0.18 \\
0.11\end{array}$ & $\begin{array}{l}0.012 \\
0.012\end{array}$ & $\begin{array}{l}0.11 \\
0.10\end{array}$ & $\begin{array}{l}2.67 \\
1.33\end{array}$ \\
\hline C & $\begin{array}{ll}0 & 30 \\
30 & 60\end{array}$ & $\begin{array}{l}5.40 \\
7.71\end{array}$ & $\begin{array}{l}0.32 \\
0.11\end{array}$ & $\begin{array}{l}0.014 \\
0.012\end{array}$ & $\begin{array}{l}0.07 \\
0.06\end{array}$ & $\begin{array}{l}1.65 \\
1.43\end{array}$ \\
\hline
\end{tabular}

\section{REFERENCES}

Abdalla, W.E. (1997). The flora of Khartooum State, with species reference to medicinal plants. M.Sc. thesis, University of Khartoum, Khartoum, Sudan

Ahmed, A.A. (1985). The grasses of northern Sudan. M.Sc. thesis, University of Khartoum, Khartoum, Sudan.

Andrews, F.W. (1948). Vegetation of the Sudan. In: Agriculture in the Sudan (ed. J.D. Tothil), Oxford University Press, Oxford.

Andrews, F.W. (1950). The flowering plants of the AgloEgyptian, Sudan (Vol.1) T. uncle and Co. Ltd. Arbroath.
Andrews, F.W. (1952). The flowering plants of the AngloEtyptian, Sudan, (Vol.11) T. Bancle and Co. Ltd. Arbroath

Andrews, F.W. (1956). The flowering plants of the AngloEtyptian, Sudan, (Vol.111) T. Bancle and Co. Ltd. Arbroath

Bebawi, f.F. and L. Neugebbohrn (1991). A review of plants of Northern Sudan, with special references to their uses. GTZ. Eschborn.

Braus, M.H., Burgstaller, A.M. Hamdoun and H. Walter (1991). Common weeds of central Sudan. GTZ. Eschborn.

Broun, A.F. and R.E. Massey (1929). Flora of the Sudan. Thomas Marby and Co., London. 
Crowfoot, G.M. (1928). Flowering lants of the Northern and Central Sudan. Orphan Printing Press, London.

El Amin, H.M. (1990). Trees and shrubs of the Sudan. Ithaca press. Exeter. London.

El Awad, A.A. (1990). Eco-taxonomical studies of Red Sea State, Sudan. Ph.D. thesis, University of Khartoum, Khartoum.

El Ghazali, G.E.B. (1985). The flora of Eastern Nuba Mountain with special reference to medicinal plants, M.Sc. thesis, University of Khartoum, Khartoum.

El Ghazali, G.E. B. (1968). Medicinal plants of Sudan, part 1: Medicinal plants of Erkawit, Natinal Coundil for Research, Khartoum.

El Ghazali, G.E..E.A. Bari, A.K. Bashir and A.K. M. Salih (1987). Medicinal plants of the Sudan, part 11: Medicinal plants of Eastern Nuba Mountains, National Council for Research, Khartoum.

El Ghazali, G.E.B., G.E.B., M.S. Egami (1994). Medicinal plants of the Sudan, part 111. Medicinal plants of Eastern Nuba Mountains, National Council for Research, Khartoum.

Elsafori, A.K. (2000). A study on the flora of Al faw Hill Central Sudan, Sudan M.Sc. thesis, University of Khartoum, Khartoum, Sudan.

Halwagy, R. (1961). Studies on the succession of the vegetation on some Islands and sand bank in the Nile near Khartoum, Sudan. Vegetation-ActaGeobotannica. 6, 4;217-234.

Harrison, M.N. and J.K. Jackson (1955). Ecologcial classification of Vegetation of the Sudan. Forest Bull No. 2. Agriculural Publicagito Committee. Khartoum.
Hutchinson, J. and J. M. Dalziel (1963). Flora of Tropical West Africa, Vol.2 ( $2^{\text {nd }}$ edition). Crown agents for Overseases Governemnts and Adminisrations, London.

Gummaa, A.N. (1985). The Flora of Ingessana Hills with Special reference to Khors. S.E. Sudan. Ph.D. thesis of Khartoum, Khartoum, Sudan.

Ibrahim, M.A.M. (1996). The flora of the Gash Delta. Eastern Sudan. M.Sc. tehsis, University of Khartoum, Khartoum, Sudan.

Index Kewensis Vol.1 and 11 (1985-1965). Clarendon Press, London.

Kordofani, M.A.Y. (1985). Experimental taxonomy of Sudanese Bulb bearing species. M.Sc. thesis, University of Khartoum, Khartoum, Sudan.

Noordwijik, M. (1984). Ecology Text Book for Suudan. Khartoum University Press, Obied, M. and Mahmound, A. (1986). The Vegetation of Khartoum Province. Sudan Notes and Records 50.135-159.

Sahni, K.C. (1968). Important Trees of The Northern Sudan. Khartoum University press.

Thirakul, S. (1968). Manual of Dendrology, Bahr El Ghazal and Central Regions: Groupepoulin, theriault, Tee Consultants, Quebec, Canada.

Wickens, G.E. (1976). The flora of JabelMarra and its Geographical Affinities. Her Majestys stationary office, London. 